\title{
Aspiration of a Dental Bridge: A Diagnostic Challenge
}

\author{
Dental Köprü Aspirasyonu ve Tanısal Zorluklar
}

Petar Jovan Avramovski ${ }^{1}$, Maja Petar Avramovska² ${ }^{2}$ Kosta Sotiroski ${ }^{3}$, Aleksandar Sikole ${ }^{4}$

\section{Abstract}

Although accidental aspiration of metal ceramic bridge is not uncommon, the number of cases reported in the literature is limited. Airway foreign bodies can become lodged in the larynx, trachea, and bronchus. The earliest symptoms which commonly appear during aspiration include coughing, chocking, and wheezing including long-term complications, such as lung abscess and pneumonia. A 73-year-old Macedonian female due to acute onset of incessant cough, dyspnea and an inspiratory and expiratory wheeze was admitted to our emergency department. Auscultation findings showed right-sided weakened vesicular breathing, closely mimicking an acute asthma exacerbation. Based on chest $X$-ray findings, the radiologist described a metallic foreign body (MFB) in the right bronchus. Using a computed tomographic (CT) scan, we confirmed 4-unit crown MFB position in the right lower lobe bronchus. Rapidly and timely intervention by bronchoscopy saved the patients from extensive reconstructive surgery.

Key words: Foreign body aspiration, metal ceramic bridge, radiography, bronchoscopy.

\section{Özet}

Metal-seramik diş köprüsünün kazara aspirasyonu çok seyrek olmamasına rağmen, literatürde bildirilen olgu sayısı sınırlıdır. Hava yoluna kaçan yabancı cisimler, larinks, trakea ve bronşlara yerleşmektedirler. Aspirasyon sırasında rastlanan en erken semptomlar, boğucu öksürük ve hırıltı iken, geç dönem komplikasyonları ise apse ve pnömoni olmaktadır. Yetmiş üç yaşında Makedon bayan hasta, akut ve sürekli bir öksürük, nefes darlığı ve hem inspiratuvar hem de ekspiratuvarda duyulan hırıltı yakınmaları ile acil servisimize başvurdu. Oskültasyonda, akut asım atağını taklit eden şekilde, sağda solunum seslerinde azalma saptandı. Radyolog, akciğer grafisinde sağ bronş sisteminde metalik bir yabancı cisim olduğunu belirledi. Tomografide, dörtlü yapıda metalik bir cismin sağ alt lob bronşunda olduğu görüldü. Hızlı ve uygun zaman içerisinde yapılan bronkoskopik müdahale ile hasta ciddi bir cerrahi girişimden kurtarılmış oldu.

Anahtar Sözcükler: Yabancı cisim aspirasyonu, metal seramik köprü, radyoloji, bronkoskopi.
'Department of Internal Medicine, Jzu Clinical Hospital Dr. Trifun Panovski, Bitola, Republic of Macedonia

2Department of Obstetrics and Gynecology, Ss. Cyril and Methodius University, Faculty of Medicine, Skopje, Republic of Macedonia ${ }^{3}$ Department Of Statistics, Prilep, St. Kliment Ohridski University, Faculty of Economics, Bitola, Republic of Macedonia

${ }^{4}$ Department of Nephrology, Ss. Cyril And Methodius University, Faculty of Medicine, Skopje, Republic of Macedonia
'Dr. Trifun Panovski Jzu Klinik Hastanesi, iç̧ Hastalıkları Kliniği, Bitola, Makedonya

2Ss. Cyril ve Methodius Üniversitesi, Tıp Fakültesi, Kadın Hastalıkları ve Doğum Anabilim Dalı, Skopje, Makedonya 3 St. Kliment Ohridski Universitesi, Ekonomi Fakültesi, İstatistik Anabilim Dalı, Prilep, Bitola, Makedonya

4 Ss. Cyril ve Methodius Universitesi, Tıp Fakültesi, Nefroloji Anabilim Dali, Skopje, Makedonya

Submitted (Başvuru tarihi): 01.11.2015 Accepted (Kabul tarihi): 01.03.2016

Correspondence (iletişim): Petar Jovan Avramovski, Department of Internal Medicine, Jzu Clinical Hospital Dr. Trifun Panovski, Bitola, Republic of Macedonia

e-mail: avramovski@gmail.com 
Although accidental aspirations of dental prostheses, partial dentures or metal ceramic bridge (MCB) are not uncommon, it has not been reported frequently in the literature. An electronic search under the term "inhaled metal ceramic bridge" yielded zero reference. After removing the quotes, search with the same term as a keyword showed more results, but most of the cases represented to us were cases with swallowed dentures. Selective search on "Google scholar" instead on "Google", with abbreviated term "inhaled dental bridge" showed only six references including this issue. The small number of obtained references in the field of inhaled foreign bodies encouraged me to show an interesting case of accidental MCB inhalation in elderly woman.

As the population of the world ages, the need to provide patients with tooth replacement through removable partial dentures or MCB is correspondingly increasing. Movement of the denture in and out of the mouth will be a routine performed daily. Using sectional or poorly designed partial dentures or MCB has led to the unexpected accident of denture swallowing or inhaled. The location of a swallowed or aspirated dental prosthesis and MCB often is accomplished radiographically, but this is difficult with prostheses constructed entirely of acrylic resins. Poly (methylmethacrylate), the plastic from which most dentures are made, is radiolucent (almost entirely invisible in $x$-ray photographs). Porcelain teeth produce light shadows on a plain radiograph but it is the metal pins attaching the teeth to the denture base that make them readily discernible. Although a plain X-ray may not well identify a swallowed or inhaled denture, the investigation has been recommended to exclude pneumomediastinum or gas within the soft tissues. A soft-tissue exposure is more likely to suggest the presence of a plastic denture than a standard exposure (1).

In adults, aspiration of teeth and dental restorations is a recognized, yet an infrequent happening in the literature (2). Main reasons for aspiration are maxillofacial trauma, dental treatment procedures, ethanol intoxication, impaired cough reflex, intubation procedures during resuscitation, and dementia $(3,4)$. Antipsychotics, anticholinergics and anxiolytics can also impair the cough reflex (4). In addition, tachypnea, resulting from various medical conditions, alters the coordination between deglutition and respiration, thereby, increasing the risk of aspiration. Current literature recognizes that impaction of aspirated objects occurred in $56 \%$ of instances within the right lower lobe and $33 \%$ in the left lower lobe (3). In the series reported by Debeliak et al. (5) 42 foreign bodies were in the right endobronchial tree, 20 were in the left, and one was in the trachea. Once aspirated, objects may subsequently change position or migrate distally, particularly after unsuccessful attempts to remove the object or if the object fragments.

Ingestion occurs more often than aspiration and usually does not cause any clinical signs or symptoms, as it is spontaneously rejected from the gastrointestinal tract in most of the cases. However, aspiration always requires specific treatment since the foreign body may cause severe obstruction and can become life-threatening (6). Airway foreign bodies can become lodged in the larynx, trachea, and bronchus. The size and shape of the object determines the site of obstruction. The large, round, or expandable objects produce complete obstruction, and irregularly shaped objects allow air passage around the object (inhaled partial dentures or $\mathrm{MCBs}$ ) resulting in incomplete obstruction.

In general, aspiration of foreign bodies produces the following three phases: first or initial stage shows choking, gagging and paroxysms of coughing, obstruction of the airway, occurring at the time of aspiration; second stage or asymptomatic phase: these signs calm down when the foreign bodies lodges and the reflex grow weary and third stage (also defined as complication phase) when the obstruction, erosion or infection cause pneumonia, atelectasis, abscess or fever (7).

The earliest symptoms which commonly appear during aspiration include coughing, chocking and wheezing. Even if the airway does not appear to be immediate jeopardy, possible early complications of foreign body aspiration may occur including dyspnea, laryngeal edema perforation and pneumothorax. Long-term complications, such as lung abscess and pneumonia, may also develop $(8,9)$. In this report, we describe an unusual case of aspiration of $\mathrm{MCB}$ and its non-surgical retrieval. We also emphasize that rapid and accurate diagnosis with early treatment results in a safe outcome for the patient.

\section{CASE}

A 73-year-old Macedonian female with a previous medical history of hypertension, chronic obstructive bronchitis, diabetes and epilepsy was admitted to the emergency room due to acute onset of incessant cough of a spasmodic nature, dyspnea, chest pain, and an inspiratory and expiratory wheeze, apparently obstructive. Upon arrival to the emergency ambulatory of internal medicine, her saturation was $95 \%$ on room air and all vital signs were within normal range. Physical examination findings 
were significant for decreased air entry on the right lung side. Auscultation showed right-sided weakened vesicular breathing, which included scattered rhonchi, and wheezing. All these findings closely mimicked an acute asthma exacerbation.

Her heart rate $110 \mathrm{bpm}$, respiration rate $38 \mathrm{r} / \mathrm{s}$ with signs of accessory muscle use, decreased breath sounds with inspiratory and expiratory wheezing. He was coughing with small amounts of white sputum. An arterial blood gas $(A B G)$ analysis showed the following results: $\mathrm{pH} 7.45$, $\mathrm{PaCO}_{2} 32.1 \mathrm{mmHg}$ and $\mathrm{PaO}_{2} 70.2 \mathrm{mmHg}$. After intravenous administration of bronchodilators, corticosteroids and inhaled anticholinergic, the condition was not significantly improved.

Auscultation differences between respiration of both lungs and $A B G$ analysis indicate radiographic imaging of the lung under suspicion for acute obstruction of respiratory tract. After chest radiography, the radiologist described MFB in the right bronchus and soft transparency difference between the left and right lung (Figure 1).

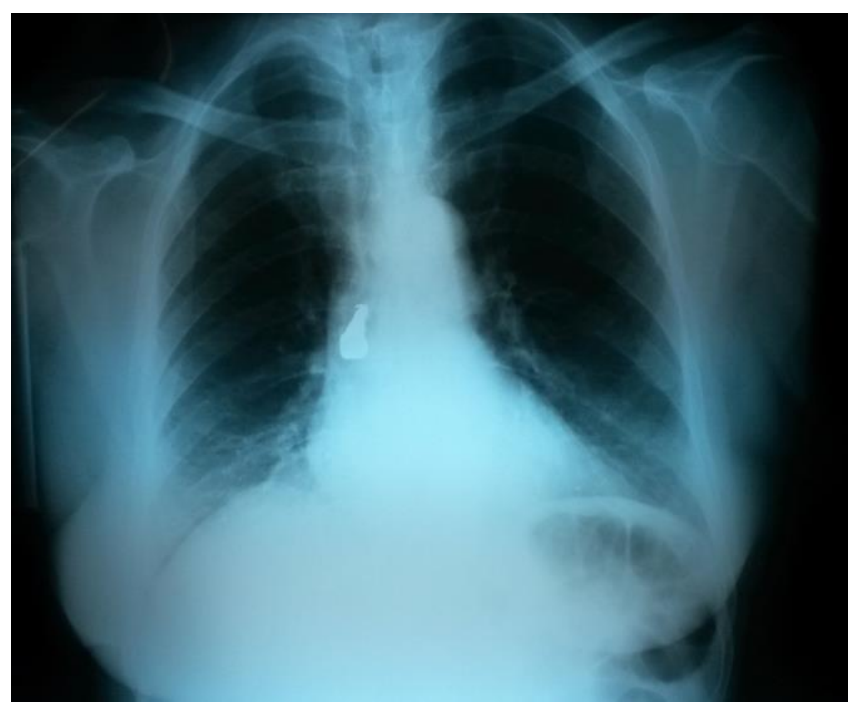

Figure 1: Chest radiograph showing metal ceramic bridge (4-unit crowns) lodged in the right mainstream bronchus (anteroposterior view of X-ray)

Better visibility of the foreign body was acquired by rightsided lateral view chest radiograph, which was made immediately after the first chest radiograph developing. At first sight of lateral radiograph, we did not recognize the nature of the metal shade located longitudinally in the right bronchus. After right clockwise radiograph rotation we noted that it was a dental creature, exactly 4-unit crowns metal bridge (Figure 2). High-resolution $\mathrm{X}$-ray showed decreased transparency (hypolucency) in the right lung which was visible as result of proximal bronchial foreign body obstruction, occurred because of less lung air content. Computed tomography (CT) confirmed the position of MCB in the right lower lobe bronchus near its origin (Figure 3). Aspirated foreign body was lodged in the right main stem bronchus, on $7.8 \mathrm{~cm}$ distance from the tracheal bifurcation, $1.5 \mathrm{~cm}$ distantly from middle lobe branches (on the transitional boundary between the right middle and right lower lobe). Before inserting flexible optical fiberscope (Olympus BF P-10, pulmonary insertion tube $5.0 \mathrm{~mm}$, biopsy channel $2.0 \mathrm{~mm}$, working length $55 \mathrm{~cm}$ ) transorally, we administrate premedication of intramuscular atropine sulfate $1 \mathrm{mg}$, midazolam and pethidine and we gave topical anesthesia of the upper and lower airways consisted of $2 \%$ and $0.5 \%$ lidocaine, respectively. Foreign body forceps was inserted and this $M C B$ was grasped and withdrawn together with the bronchoscope. It was found to be inhaled MCB with 4-unit crown, presented in figure 4 . The size of retrieved foreign body was: $26.3 \times 8.2 \times 6.3 \mathrm{~mm}$.

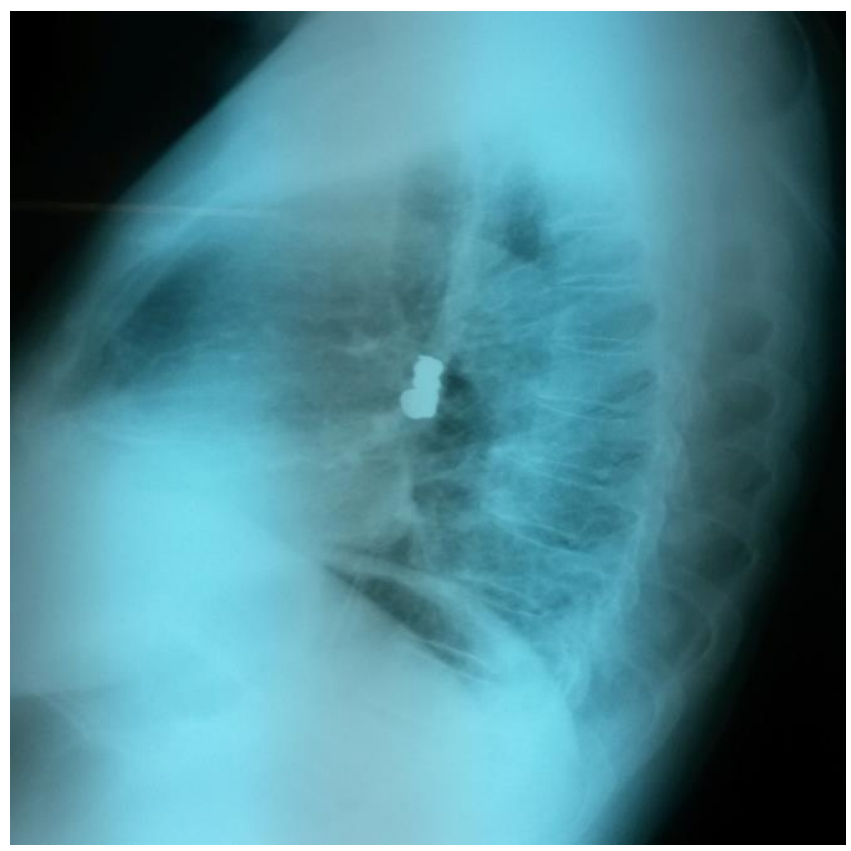

Figure 2: Chest lateral view radiograph showing metal ceramic bridge (4-unit crowns) lodged in the right lung

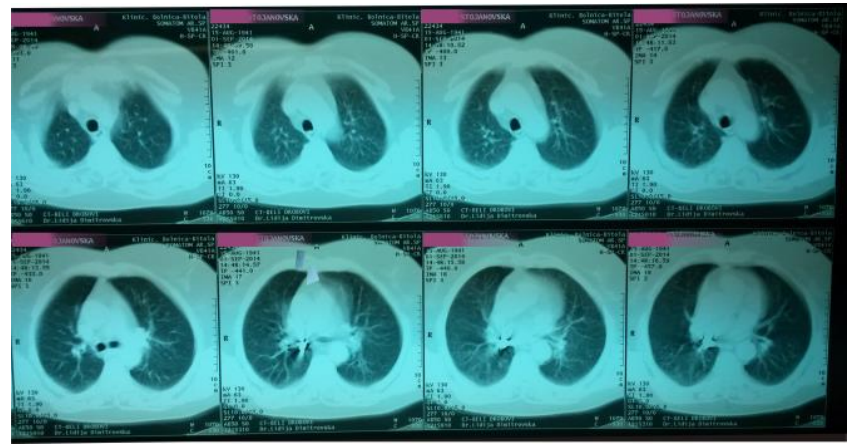

Figure 3: CT scan (sliced layer-by-layer) of upper thorax showing inhaled metal ceramic bridge (4-unit crowns) lodged in the right mainstream bronchus 


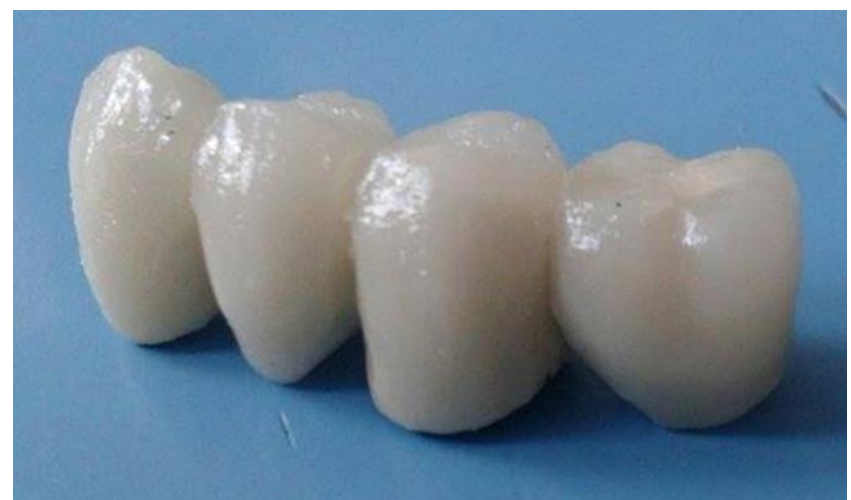

Figure 4: Retrieved aspirated metal ceramic bridge

\section{DISCUSSION}

Patients, who inhaled a foreign body, usually fail to improve with conventional bronchodilators. However, the absence of atopy, the acute onset of symptoms, and unilateral physical findings may suggest foreign body aspiration. Thus, clinical suspicion is crucial in the diagnostic process.

In our case, the medical history revealed that she had primary epilepsy for seven years, diagnosed with generalized tonic-clonic type with a frequency of four or more attacks per year. During the clonic phase, the tongue or cheek can be bitten and frothy and bloody saliva may be expectorated from the mouth. Displacements of prosthesis increase the risk for possible aspiration of the prosthesis into the upper respiratory tract. Although our case had no such an incident about how she inhaled the dental bridge, the symptoms of wheezing and history for epilepsy headed to doubt about the inhalation of a foreign body in the course of last epileptic seizure.

Zitzmann et al. (10) suggest that if the aspirated or ingested foreign body cannot be coughed out, it is mandatory to take frontal and lateral chest radiographs to identify the objects position in the intestinal system or the tracheobronchial tree. It should be ensured that airway is not obstructed and the patient is informed about the problem. The patient was very surprised when told to her that her dental bridge was inhaled in her airway. She confirmed the lack of her dental bridge that happened a day before during an epileptic seizure.

Furthermore, acute obstruction can be life-threatening and delaying the removal of foreign objects may make a bronchoscopy technically more difficult. Fiber optic is a preferable option in contrast to rigid bronchoscopy in the case of a distally wedged foreign body. The flexible bronchoscope can provide access to subsegmental bronchi beyond that provided by the rigid bronchoscope. If gas exchange is already compromised or if insertion of the flexible bronchoscope would result in significant impairment of gas exchange, flexible bronchoscopy is contraindicated. We used the optical fiber bronchoscopy to confirm, localize, and visualize the foreign body in the distal part of tracheobronchial tree. Fiber bronchoscopy is considered a diagnostic test of choice for the initial diagnosis of foreign body in adults. The advantages of this technique over rigid bronchoscopy are that it can be performed under local anesthesia, visualization of smaller peripheral airway is betters with relatively easier manipulation in patients with deformations of cervical spine and pharynx (11).

Welcker et al. (12) reported a case of failed bronchoscopy removal of the foreign body, resolved by lobectomy of right lower lobe performed because of chronic pneumonia. Surgical extraction of foreign body through bronchotomy or even segmental resection under general anesthesia is the last resort, if extraction using bronchoscopy is unsuccessful.

Foreign bodies can remain undetected for months in adults which require a high index of suspicion for diagnosis as most adults do not recall a history of choking (13). In our case, due to her comorbid chronic obstructive disease, the symptoms of wheezing and choking did not remain undetected, even in this case of incomplete obstruction with foreign body. Based on the findings of Martinot et al. (14) who suggested an algorithm for managing suspected foreign body aspiration evaluating the risk of foreign body based on the patient's history, presence of diminished breath sounds, and findings on chest $X$-ray, we found the aspirated foreign body early.

Dental prosthetics such as the dental bridge aspirated by our patient represent up to $27 \%$ of cases $(15,16)$. We believe that this percentage is significantly higher, due to the fact that many foreign bodies are incidentally seen on radiographic imaging ordered for symptoms mistakenly attributed to other medical conditions including chronic obstructive disease, asthma and unresolved recurrent pneumonia. Immediate removal of tracheobronchial foreign body is essential to prevent life-threatening complications. Fortunately, we were able to remove the foreign body within the first six hours after its inhalation.

Due to the epileptic seizure in our case, after being examined by the neurologist (because of choking and coughing), she was referred to internal medicine ambulance. If a diagnosis of foreign body aspiration is delayed, a retained foreign body may result in unresolving pneumonia, lung abscess, and bronchiectasis. Also, formation of 
granulation tissue around the foreign body may occur and may resemble bronchogenic carcinoma $(2,16)$.

Another lucky circumstance that helped foreign body detection is the structure of denture: the denture was built of metal base under the porcelain cover. Therefore, removable partial dentures should be designed not only to preserve the remaining teeth, but also to prevent accidental swallowing of these appliances. Manufacturers are advised to increase the radio opacities of these acrylic appliances to facilitate their identification after accidental swallowing or inhalation.

After the bronchoscopy intervention, in the next five days, the patient was under bronchodilators, antibiotics, and corticosteroid therapy. The control roentgenography did not show any pathological findings. The gas analysis $\left(\mathrm{pO}_{2}\right.$ and $\left.\mathrm{pCO}_{2}\right)$ and the overall clinical state were normalized in the next day. Removed foreign body was given to the patient as a souvenir in remembrance of the unpleasant event: epileptic seizure with inhalation of $M C B$ and provocation of asthmatic attack that was fully resolved.

It would be a great advantage if dentist used X-ray opaque material for dentures. Quick radiography diagnoses and quick timely appropriate intervention by bronchoscopy removal saved the patient from extensive reconstructive surgery and maybe her life.

\section{CONFLICTS OF INTEREST}

None declared.

\section{AUTHOR CONTRIBUTIONS}

Concept - P.J.A., M.P.A., K.S., A.S.; Planning and Design - P.J.A., M.P.A., K.S., A.S.; Supervision - P.J.A., M.P.A., K.S., A.S.; Funding -; Materials -; Data Collection and/or Processing - P.J.A., K.S., A.S.; Analysis and/or Interpretation - P.J.A., M.P.A., K.S.; Literature Review - M.P.A., A.S., P.J.A.; Writing - P.J.A.; Critical Review - P.J.A., M.P.A.

\section{YAZAR KATKILARI}

Fikir - P.J.A., M.P.A., K.S., A.S.; Tasarım ve Dizayn P.J.A., M.P.A., K.S., A.S.; Denetleme - P.J.A., M.P.A., K.S., A.S.; Kaynaklar -; Malzemeler -; Veri Toplama ve/veya İşleme - P.J.A., K.S., A.S.; Analiz ve/veya Yorum P.J.A., M.P.A., K.S.; Literatür Taraması - M.P.A., A.S., P.J.A.; Yazıyı Yazan - P.J.A.; Eleştirel Inceleme - P.J.A., M.P.A.

\section{REFERENCES}

1. Nageris B, Feinmesser R. Dentures in the esophagus complicated by pneumomediastinum. Ear Nose Throat J 1990; 69:775-6.

2. Ellakwa A. Damage caused by removable partial dentures: reality? Dentistry 2012; 4:e107. [CrossRef]

3. Basoglu OK, Buduneli N, Cagirici U, Turhan K, Aysan T. Pulmonary aspiration of a two-unit bridge during deep sleep. J Oral Rehabil 2005; 32:461-3. [CrossRef]

4. Emodi $O$, Imad $A E$, Blanc $O$, Aizenbud D. Aspiration and ingestion of dental instruments-diagnosis, treatment and prevention. Refaut Hapeh Vehashinayim 2006; 24:50-8.

5. Debeliak A, Sorli J, Music E, Kecelj P. Bronchoscopic removal of foreign bodies in adults: experience with 62 patients from 1974-1998. Eur Respir J 1999; 14:792-5. [CrossRef]

6. Singh G, Gambhir RS, Singh S, Kaur H. Accidental aspiration of dental crowns and retrieval. J Contemp Dent Pract 2012; 13:716-8. [CrossRef]

7. Rodríguez H, Passali GC, Gregori D, Chinski A, Tiscornia $\mathrm{C}$, Botto $\mathrm{H}$, et al. Management of foreign bodies in the airway and oesophagus. Int J Pediatr Otorhinolaryngol 2012; 14 Suppl 1:s84-91. [CrossRef]

8. Milton TM, Hearing SD, Ireland AJ. Ingested foreign bodies associated with orthodontic treatment: report of three cases and review of ingestion/aspiration incident management. Br Dent J 2001; 190:592-6. [CrossRef]

9. Gautam R, Singh SV, Singh K, Arya D. Extracoronal precision attachments in a patients with generalized tonic-clonic seizures. J Stomat Occ Med 2012; 5:130. [CrossRef]

10. Zitzmann NU, Fried R, Elsasser S, Marinello CP. The aspiration and swallowing of foreign bodies. The management of the aspiration or swallowing of foreign bodies during dental treatment. Schweiz Monatsschr Zahnmed 2000; 11:691-32.

11. Oke V, Vadde R, Munigikar P, Bhattarai B, Agu C, Basunia R, et al. Use of flexible bronchoscopy in an adult for removal of aspirated foreign body at a community hospital. J Community Hosp Intern Med Perspect 2015; 5:285589. [CrossRef]

12. Welcker K, Nakashima M, Branscheid D. Aspiration of dental implant-reasons, management and prevention. Pneumologie 2005; 3:174-7.

13. Yilmaz A, Akkaya E, Damadoglu E, Gungor S. Occult bronchial foreign body aspiration in adults: analysis of four cases. Respirology 2004; 9:561-3. [CrossRef] 
14. Martinot A, Closset $M$, Marquette $C H$, Hue V, Deschildre $A$, Ramon $P$, et al. Indications for flexible versus rigid bronchoscopy in children with suspected foreign-body aspiration. Am J Respir Crit Care Med. 1997; 15:16769. [CrossRef]

15. Umesan UK, Chua KL, Balakrishnan. Prevention and management of accidental foreign body ingestion and aspiration in orthodontic practice. Ther Clin Risk Manag 2012; 8:245-52. [CrossRef]

16. Nigam BK. Bronchial foreign body masquerading as a lung carcinoma. Indian J Chest Dis Allied Sci 1990; 32:43-7. 